\title{
Educational Governance Innovation through Implementation of Four UNESCO Education Pillars
}

\author{
Dita Anggraini Nurjannah Musliman \\ Department of Education Management \\ Universitas Negeri Surabaya \\ Surabaya, Indonesia \\ Ditaanggraini.nm95@gmail.com
}

\begin{abstract}
The purpose of this research was discussion about educational governance innovations through the implementation of four UNESCO pillars. This was a descriptive research that used a qualitative approach. The data was collected through observation, interviews and documentation. The results and discussion of this study are the achievement of a pleasant learning atmosphere with the innovation of educational governance through the implementation of four pillars of UNESCO education in this school.
\end{abstract}

Keywords-educational governance; innovation; UNESCO Education Pillars

\section{INTRODUCTION}

In the teaching and learning process, there are many obstacles that arise from students. The constraints in question are internal constraints of students, namely laziness and lack of confidence. For this reason, in the teaching and learning process, innovation is needed. With the existence of Innovation, students can be supported to succeed the teaching and learning process. The statement of the number of obstacles that exist from students is not only limited to that. In addition to the constraints of the lack of innovation from the teacher, there is a diversity of types of students, each of whom cannot accept the same teaching method [1].

As a mediator and facilitator, the teacher has to anticipated this. For this reason, teachers must be skilled in applying innovation in classroom management needed by different types of students [2]. Therefore, needs to study of skilled understanding in applying Innovation through the education of 4 pillars of UNESCO in the management of classes needed by different types of students.

ABA Kindergarten is one of the pre-school educational institutions that wants to commit and continue to improve the education and teaching system for students [3]. The awareness of the complex educational needs such as limited facilities, the ability of teachers who are not optimally professional, or the standard teaching process that not suitable with the procedure. So, that causes the course of education in some places hampered progress and tend to be what they are. Positive approaches and superior programs designed must be suitable with the needs of students as outlined in the 4 pillars of
UNESCO education. Based on the problems above, the researcher wants to describe the Innovation in Child Friendly Education Governance through the Implementation of 4 UNESCO Main Pillars of Education in Krian ABA Kindergarten.

\section{METHOD}

In this study, researchers used a qualitative descriptive research method. With the technique of collecting data by means of observation and interviews. The researcher made a direct observation of how to implement the education innovation management in the ABA Kindergarten school [1]. the things that the researcher observes are the readiness of the teacher in preparing the material, the atmosphere and conditions of the place of teaching and learning and student responses. Interviews are conducted to obtain more concrete or comprehensive data that we cannot find or obtain in the observation process. here the researcher conducted an interview with the head of the curriculum in the ABA Kindergarten school to strengthen the results and data obtained when making observations.

\section{RESULTS AND DISCUSSION}

Some ABA kindergarten programs are formulations of Best Practices prepared for 1 year by the Teacher team [3]. The series of programs are governance innovations that are packaged in a friendly manner and are the implementation of the 4 pillars of UNESCO education [4]. Here is a description of the innovations found in ABA Kindergarten: (1). Learning to know: As explained in the rational, the first pillar of UNESCO's education is learning to know the learning needs themselves. In this case, ABA Kindergarten packages in a learning process that is interesting for children and interactive learning stages. There are 11 learning centers which are termed "countries". Strengthened by using the BCCT or SELING approach we convey to children that they are playing in a country [5]: (a) in the land of Alam Raya children learn about natural materials and simple science. The Scope of Natural Intelligence and stimulate children to experience exploration. (b). Athletic Country: is a country where children practice physical activity, especially gross motor skills and 
dexterity. The scope of kinesthetic intelligence and provide learning experiences with locomotor optimally. (c) Culinary Country: inspired by Italian for children - carrying out cooking classes. Implementation of innovation on the concept of success in special self-help, helping parents in the kitchen, processing simple healthy food ingredients, and applying a clean and healthy environment. (d) Country Alphabet: is a country where children are engaged in fine motoric needs for pre-preparation writing or pre-reading. Children also know colors, numbers, letters and make simple diaries. (e) Country Architect: the same as the center of the beam in the SELING approach. In Architect Country, children learn about construction, classification, stages of playing development, and working in teams. The intelligence scope of mathematic and spatial logic. It is important for the competency of the child to master the stages of classifying in a simple and complete manner. [7] In this Architects country, children always get the opportunity to design their competency based on their respective achievements. The language of the Architects provided is also unique to understand them the task of building is carried out by experts. (f) Pious Children Country: Alhamdulillah (thanks to god), children are very happy to be in the land of pious children (center of religions) because they can arrange mosques, know the procession of Umrah or Hajj, practice prayers and memorize prayers and hadith pleasantly. (g) The Land of Imagination: making hand puppets, expressing love for the environment by making miniature trees and rice fields together, also called Micro play. The scope of Intrapersonal intelligence. From this imaginary country, children will learn more about objects through miniature. (h) Country STORY: This is another name for the Role Center / Macro play. Emphasis on children's language development. In this country children are very interested in the process. Like moving markets, malls, stations, or zoos in their study and play rooms. This is an innovation from the implementation of Learn to Know. Children will learn directly and practice what they are learning. (i) Country of Creation: Art and creativity are a favorite of children. Producing a work, that is the project in each theme discussed. The scope of plural intelligence is also very prominent in the country of this creation. Spatial intelligence, natural and musical stimulus from this country

(j) Negeri (land) of Melody: in the land of melodies, children know percussion instruments and make it themselves. This is the thing that makes children very enthusiastic. The Musical Intelligence Scope and playing percussion can provide special learning energy for children. (k) English Land: is one of the learning centers that provides different nuances of knowing the simple language of the world (English) through activities that are "fun and amazing"

The 11 countries above made the children miss the days when they were very curious "where do I study today?" "What did I do in the country?" this. [7] Equipped with the need for the process of "knowing" in each country through stages: planning, exploring, doing, communicating, and reflecting. Interesting, because the process of knowing is really gradual. [8] In UNESCO's note that learning is a process they understand the need for "why should you learn about something". Therefore, in every country, everything starts from a learning preparation and a big question. They have the opportunity to pour ideas (exploring), and do what has been conveyed in their ideas. Continue to make effective communication so that children have the concept of "dare to ask". (2). Learning to do: thematic learning activities (PAT). On the occasion of writing this paper, we enthusiastically told how the process of children learning directly. Packed the game in the "Final Theme Celebration" held by ABA Kindergarten. [9] In semester 1 the children learned about sharing with another who needs, the next plan, at the final celebration of the theme we invited the orphanage children to our schools and directly the children shared what they had packed. Some are in the form of bread parcels, toys or snacks. Direct experience makes children have many questions. An example is the final celebration of the theme "technology". The children discussed about my traditional games are made of and immediately sensed some of today's technological toys that were brought to school and transformed into "my city play". So, that there are meaningful questions like "Ustadzah, how come the balloon house can't erupt?" "Is the jet costed driven by the engine? Or people? " Very nice.

Final Celebration This theme is held every 2 months and is carried out simultaneously as an implementation of learning that has been done in countries. Preschool is a golden opportunity to grow great experiences. Every school especially Kindergarten should have this to understand. [10] Learning to Do is a condition where what the teacher gives as a lesson can be done by children - children are not limited to theory or try to work on the questions on white sheets. Celebration The end of the theme is one of the ways to implement what the children can do can be proven and become an unforgettable experience.

(3). Learning to be: ABA character / student profile press points compile in the process of implementing the 3rd pillar, namely learning to be "what is already known and learned". For this reason, it needs to be supported by the formation of characters that form identity. Because early age or early age is the right time to make a statement about goodness or positive things.

(4). Learning to live together: harmonious living habits between students, including inclusion students [11]. Understanding the existence of these different child friends is the task of innovating the implementation of the UNESCO education pillar. Therefore, ABA Kindergarten formulates the needs of children with special needs categories in a container called "Growth Center". is one of the units within the ABA Education Institution that helps the process of optimizing the growth and development of children in ABA schools and society in general. Who provides services by prioritizing the needs of each child's uniqueness as individuals who develop according to the stage of development.

\section{CONCLUSION}

From the background, formulation, discussion, rational and description, we can gather that: The governance of education for early childhood (kindergarten level) can be carried out in an innovative and child-friendly manner through the Implementation of Unesco's 4 Education Pillars. Whereas 
starting from the initial education level (pre-school), a series of programs for excellent programs is needed which include innovation and friendliness in the process.

From this paper, the authors hope that some parties can synergize with each other, especially on the need for continuous educational achievement and be able to provide provisions for students to survive in their environment. (1) To the government: the progress of the world of education especially in Indonesia is in dire need of full support from the government. Primarily in the strategy of getting quality schools and graduating students who excel in achievement. Therefore, the authors hope that the government will be more active in providing training programs, periodic coaching, information about education whose general direction is UNESCO foundations, or comparative study programs in its efforts to expand knowledge about successful education in other parts of the world. (2) To School Managers: I hope this paper can be an encouragement to continue to provide opportunities and opportunities in planning innovative and child-friendly programs as implemented so far.(3) To the lifelong dedication of the Teachers: I hope this lesson can bring great inspiration to provide the best education for our students, especially comprehensive and sustainable education.(4) Finally to the parents whose mandate to educate children is extraordinary, that this paper was made in order to provide extensive information, not only for schools, but also can be applied in children's education when at home. Because the best education is a role model, and role model is very close to friendliness and regularity. Innovations in the family are also needed by children so that the harmony and knowledge they receive is sustainable at school, at home, or in the community.

\section{REFERENCES}

[1] A Fidalgo, Blanco. 2017. Knowledge Spirals in Higher Education Teaching Innovation. International Journal of Knowledge Management (IJKM) 10 (4), 16-37.

[2] Arsaythamby. Veloo, 2017. The Effect of Clinic Supervision on The Teaching Performance of Secondary School Teachers. International Journal of Social and Behavioral Sciences.2 (93), 35-39.

[3] Van den Berg, R. 2018. Teacher's Meanings Regarding Educational Practice. Review of Educational Research 72 (4), 577-625

[4] Bracey, G. W. 2016. On the Death of Childhood and the Destruction of Publish Schools: The Folly of Today's Education Policies and Practices. Portsmouth, NH: Heinemann.

[5] http://www.unesco.org/new/en/archives/education/themes/leading-theinternational agenda/education-for-all/

[6] McLaren, P. 2015. Life in Schools: An Introduction to Critical Pedagogy in The Foundations of Education (6th ed). New York: Longman.

[7] Musfah, J. Manajemen Pendidikan, Aplikasi, Strategi, Dan Inovasi. Jakarta: prenadamedia.

[8] Susanto, Ahmad, 2011: Perkembangan Anak Usia Dini. Jakarta: Fajar Interpratama Offsite.

[9] Chatib, Munif, 20015. Sekolahnya Manusia. Bandung: PT Kaifa.

[10] Christopher, D. 2017. School Reform and Transitions in Teacher Professionalism and Identity. Handbook of Teacher education, 597-612

[11] Tillman, Diane. 2015. Living Values Activities for Children Age 3-7. 